\title{
COMPARATIVE ANALYSIS OF THE ECONOMIC SITUATION BEFORE AND AFTER THE OUTBREAK OF THE PANDEMIC SITUATION IN ALBANIA
}

\author{
Observation Analysis on the Official Publications of the Albanian Government
}

\author{
Dr. Tatjana ELEZI ${ }^{1}$ \\ Bojken Llambro ${ }^{2}$ \\ Prof. Dr. Alba DUMI ${ }^{3}$ \\ ${ }^{1}$ Canadian and Tirana Business University College \\ Head of Accounting \& Finance Department \\ tatjana.elezi@tbu.edu.al \\ ${ }^{2}$ University of "Ismail Qemali” Economics \\ bojken.1lambro@gmail.com \\ Tirana Business University College \\ ${ }^{3}$ Vice Dean TBU University Tirana, Albania \\ alba.besi12@gmail.com
}

\begin{abstract}
COVID-19 hit Albania's firms' finances hard. While a similar share of firms reported decreased liquidity and cash flow availability across the countries, 58\% of firms in Albania reported delaying payments to their suppliers, a share considerably higher than in the other seven countries.

COVID-19 has the potential to cause three waves of morbidity and mortality: the first is due the disease itself; the second to the inability of health systems to maintain health services, 1 and the third is due to increased levels of unemployment, poverty, economic repercussions, disruption to social services and social systems, and increasing inequalities. Based on current evidence, the most plausible scenario for the evolution of the pandemic may involve recurring epidemic waves interspersed with periods of lower-level transmission.

The challenge for the government and the health system in a recurring epidemic wave scenario with compounding waves of mortality and morbidity is to remain ready to provide the full range of services needed to prevent, diagnose, isolate and treat COVID-19 patients, while providing the full spectrum of health services and strengthen its health system towards Universal Health Coverage. This requires a dual track health system response which will test many countries.
\end{abstract}

Key words: Empirical Study of COVID 19, Pandemic plan, Health system, Albania reforms Empirical studies of COVID 19, Recurring epidemic, Accounting's politics,

JEL Classification : N0, N1, N2, N3, O1, O2, O3.

\subsection{INTRODUCTION}

In addition, it is imperative to plan and implement well-coordinated social and economic measures, responses and strategies that reduce the negative far-reaching socioeconomic impact of the pandemic on people, the economy, social systems and services. While the number of COVID-19 cases in Albania began to stabilize by mid-December, the situation has deteriorated again as of January $2021 .{ }^{1}$ While the

\footnotetext{
${ }^{1}$ The International Institute of Finance (IIF) responded to this initiative by recommending that private sector creditors repay debt in a similar way. In May, the IIF issued Terms of Reference for private sector participation on a voluntary basis.
} 
ISSN 2661-2666 (Online) International Scientific Journal Monte (ISJM) DOI: 10.33807/monte.20211916 Volume 4, (No).2 (2021): April

daily rate of new cases decreased to a low of 185 new cases per day on 4 January, this was most likely due to less testing during the holiday period, as the situation quickly reversed to more than 800 cases per day again. Albania ${ }^{2}$ is currently ranked 15th in the world with 971 active COVID-19 cases per 100 000 inhabitants. As of 31 January, a total of 1380 people has died from the virus, representing 46 deaths per 100000 inhabitants.

COVID-19 has also created an environment of uncertainty.

Figure 1. Impact on demand and sales
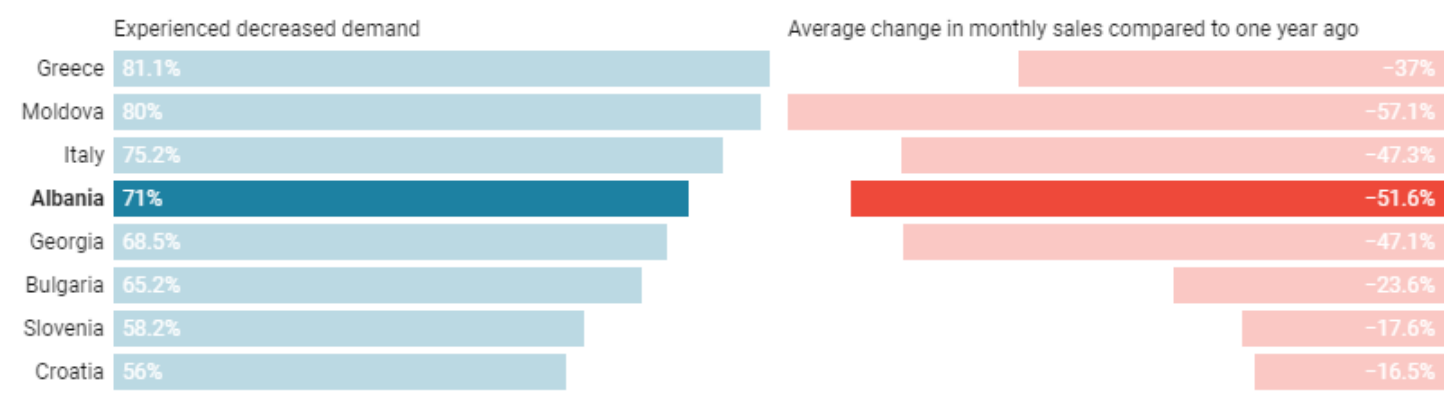

Source: World Bank Enterprise Surveys Follow-up on COVID-19 • Get the data · Created with Datawrapper

The IMF, together with the World Bank, has expressed support for a further extension of the DSSI by the end of 2021. The G20 have agreed to consider the need for a further extension until the time of the IMF-World Bank Spring Meetings in April 2021, pp 3

${ }^{2}$ Source: COVID-19 health situation - December 2020/January 2021 
ISSN 2661-2666 (Online) International Scientific Journal Monte (ISJM) DOI: 10.33807/monte.20211916 Volume 4, (No).2 (2021): April
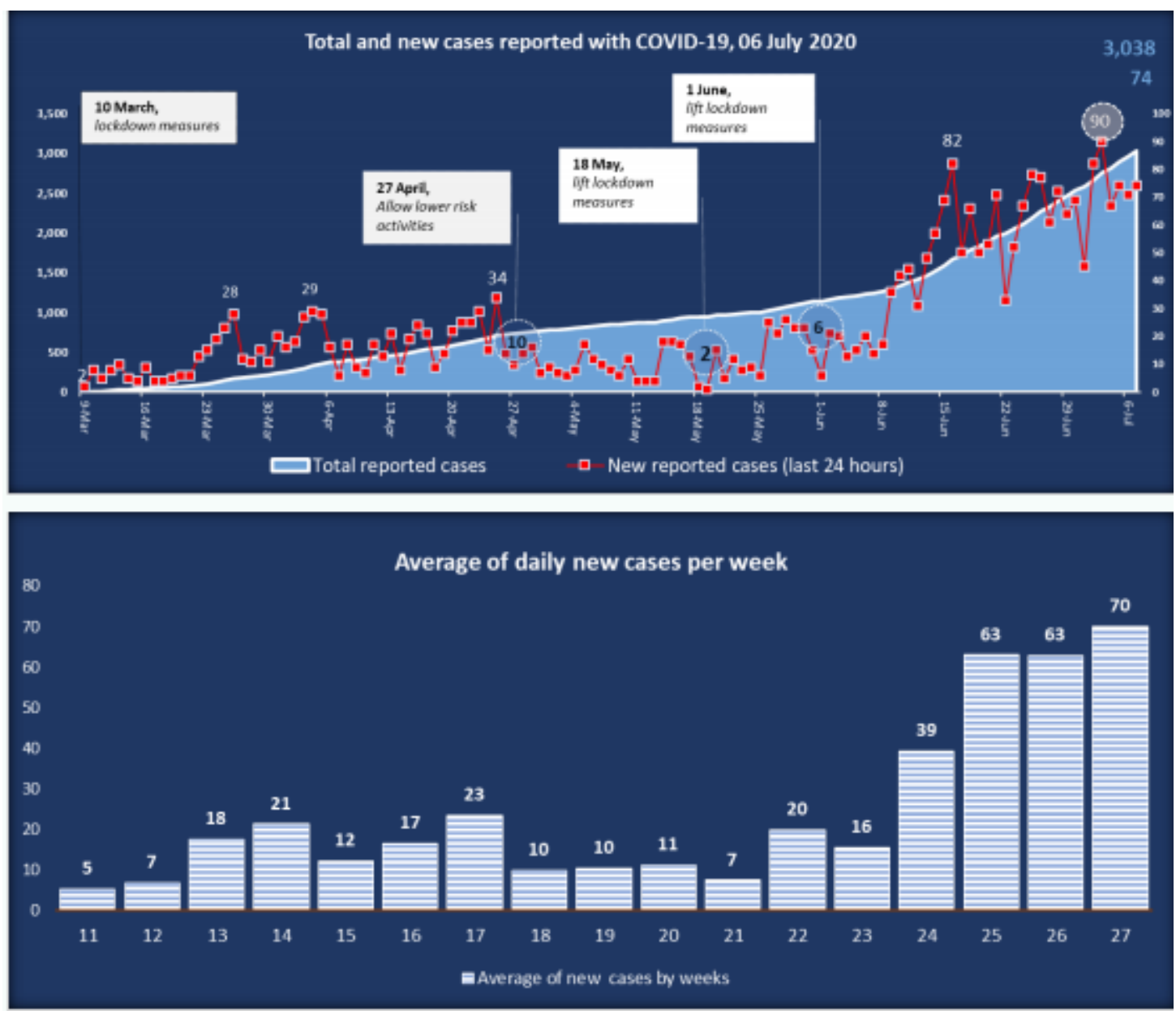

Source: THE COVID-19 CRISIS IN ALBANIA @ OECD 2021

\section{GENERAL INFORMATION}

Albania's COVID-19 public health ${ }^{3}$ preparedness and response are maintained and reinforced, capacity of ensuring safe delivery of essential health services and recovery boosted, and the health system strengthened towards integrated Universal Health Coverage. Social ${ }^{4}$ protection and social services are provided to people at risk to cope with adversity. Decent-work and economic recovery programmers are enacted for protecting jobs, supporting small and medium-sized enterprises, and safeguarding the most vulnerable productive sectors. Albania entered the COVID-19 crisis soon after the destructive earthquake in November 2019. ${ }^{5}$ The COVID-19 outbreak hit Albania even harder. To explore the ramifications of this unprecedented shock on Albanian firms, the World Bank's Enterprise Analysis Unit and IFC undertook a survey in June 2020, re-contacting the same businesses that participated in the Enterprise Survey in 2019. This blog summarizes findings from the survey and contrasts the impacts of COVID-19 on the Albanian private sector with those observed in Georgia, Moldova, Italy, Greece, Bulgaria, Slovenia and Croatia.

\footnotetext{
${ }^{3}$ Source: https://www. unicef.org/albania/media/3101, worldbank.org/developmenttalk/covid-19-impact-albanias-private-sector-taking-stock-looking-ahead

${ }^{4}$ World-bank.org/developmenttalk/covid-19-impact-albanias-private-sector-taking-stock-looking-ahead pp 2 5 Fernando Blanco, Levent Karadayi, Nona Karalashvili, Laureta Qorlazja,January 04, 2021
} 
a) Macroeconomic policies are adopted to manage the expected surge in fiscal and financial stimulus in favors of the most vulnerable, and in coherence with multilateral and regional responses.

b) Social dialogue, political engagement, and investment in community-led resilience and local government response systems are enhanced in order to promote social cohesion.

c) Various states have closed their borders and instructed people to stay inside their homes.

In other words, the world has remained in abeyance, causing a global economic downturn and creating new risks for entities. These risks ${ }^{6}$ have begun to present challenges both operationally and financially. In the coming days and weeks, entities will assess risks more clearly, as well as respond to new challenges with greater confidence. Entities should also consider the implications of COVID-19 in the context of their financial reporting. Management considerations ${ }^{7}$ and efforts may focus on the preparation of the books of account, the assessment of continuity, the calculation of the accounting estimates and the determination of fair values, and the information.

\section{LITERATURE REVIEW AND HYPOTHESES}

There is no analogous situation in modern times. There is a consensus among experts that the "economic pain" will pass in several waves: The first wave is the "unplanned stop", so almost all economic activities throughout the country suddenly stop. A few weeks ago, people went to work, ate at restaurants, paid for their services, booked trips and vacations, planned car purchases, were considering buying a new home, held trainings, and conference.

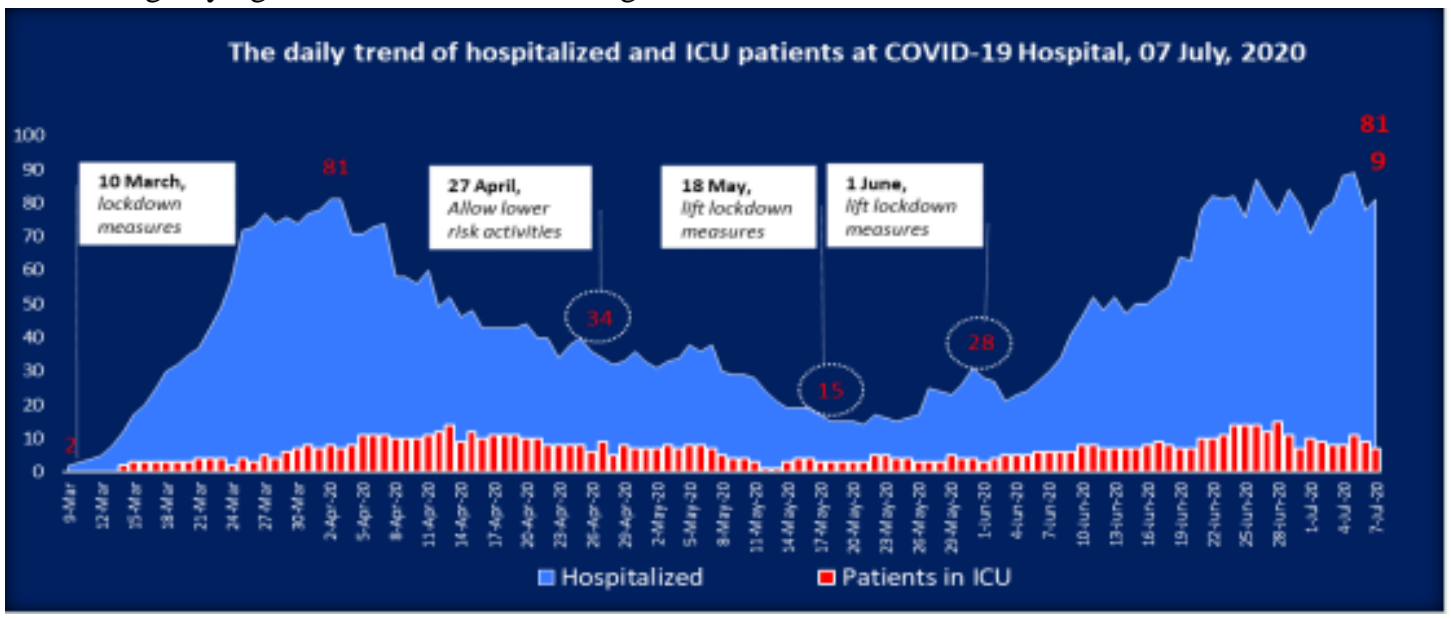

Source: THE COVID-19 CRISIS IN ALBANIA @ OECD 2021

Now, almost everything is stopped. People have found shelter and security in their homes and are passive. In the second wave, when everything is stopped, people can gradually lose their jobs. In the third wave, all those who may lose their jobs ${ }^{8}$ or those at risk of losing their jobs will be in a panic, not from the pandemic, but from anxiety about the future. No one will buy the new car, the new house, or plan a vacation this summer. Although much of the restrictions imposed to prevent the spread of the COVID-19 pandemic will be phased out, consumer reluctance will slow economic growth for a much longer time after the end of the COVID-19 pandemic.

\footnotetext{
${ }^{6}$ Worldbank.org/developmenttalk/covid-19-impact-albanias-private-sector-taking-stock-looking-ahead

${ }^{7}$ OECD COVID-19 cases in Albania, pp 2

${ }^{8}$ Worldbank.org/developmenttalk/covid-19-impact-albanias-private-sector-taking-stock-looking-ahead, pp11
} 


\section{Evolution of active cases in Albania}

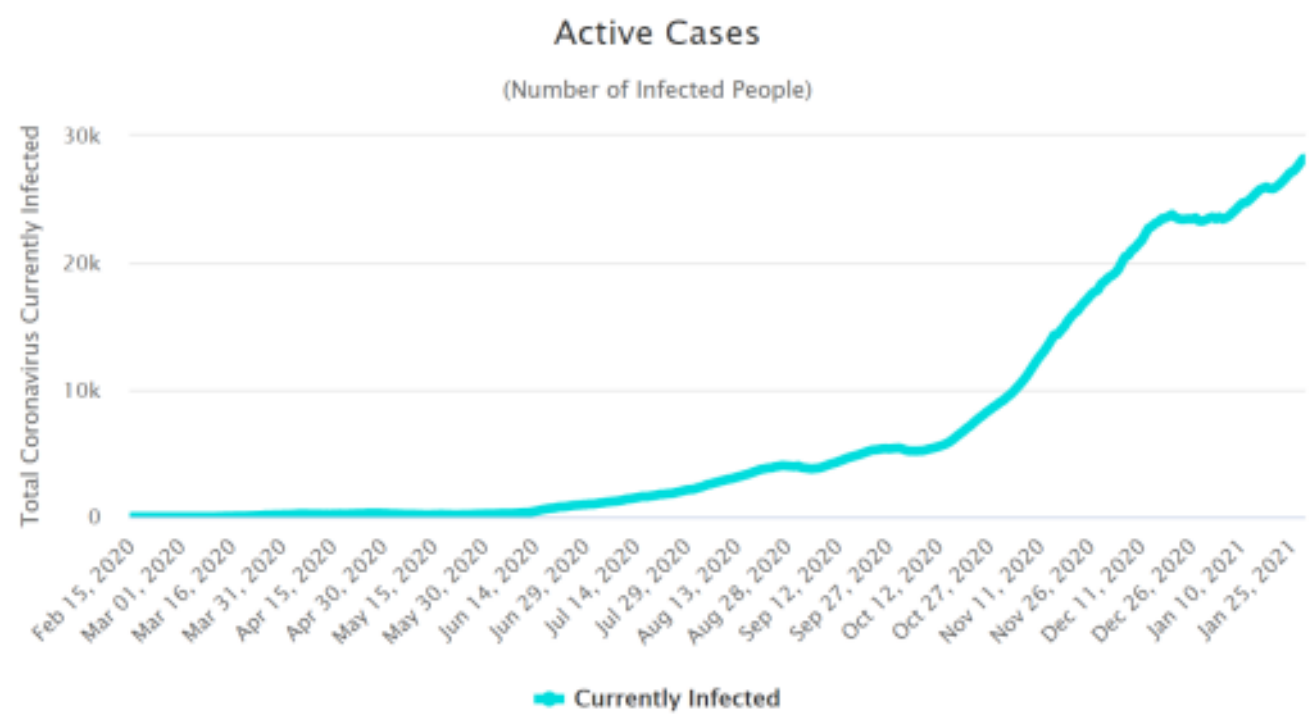

Source: THE COVID-19 CRISIS IN ALBANIA @ OECD 2021

In the fourth wave, businesses that have planned investments will give up any new investments whether in new product lines, new product development, or investments in new workspaces and thus an engine. In the report on the world economy, published in the second week of April, the International Monetary Fund ${ }^{9}$ characterizes the economic crisis caused by the COVID-19 pandemic, as a crisis that we have not seen never before and therefore has a great deal of uncertainty about its impact on people's lives. Most countries ${ }^{10}$ in the world are facing at the same time a health crisis, financial crisis and a drastic drop in the price of raw materials, including oil. An adjustment to employment in Albania has been very widespread. Twenty eight percent of firms reduced the number of permanent workers, a much higher share than in Greece, Italy, Moldova and Croatia, but comparable to the other countries. On average, Albanian firms cut their number of permanent full-time workers by $11 \%$ which is significantly worse than in Greece, Italy and Croatia, though better than in Georgia, and comparable to levels in Slovenia, Moldova and Bulgaria. Differentiated impacts on employment may have been partially associated with the structure of the governments' COVID-19 support packages.

${ }^{11}$ According to the International Monetary Fund ${ }^{12}$ projections, the global economy will fall to $-3 \%$, which is a decrease of 6.3 percentage points, compared to the projections of January 2020. This decline is expected to cause the most negative recession we have seen, which from the "Great Depression" crisis and much more negative than the 2008 global financial crisis

\footnotetext{
${ }^{9}$ This paper is published under the responsibility of the Secretary-General of the OECD. The opinions expressed and arguments employed herein do not necessarily reflect the official views of OECD member countries.

This document and any map included herein are without prejudice to the status of or sovereignty over any territory, to the delimitation of international frontiers and boundaries and to the name of any territory, city or area.

The use of this work, whether digital or print, is governed by the Terms and Conditions to be found at http://www.oecd.org/termsandconditions.

${ }_{10}^{10}$ ASSCT in Albania analyses, 2021, pp 11

${ }^{11} \mathrm{https}$ //www.unicef.org/albania/media/3101/file/UN\%20ALBANIA\%20COVID-19\%20SOCIOECONOMIC\%20RECOVERY\%20\&\%20RESPONSE\%20PLAN.pdf

${ }^{12}$ Worldbank.org/developmenttalk/covid-19-impact-albanias-private-sector-taking-stock-looking-ahead, pp 16
} 
ISSN 2661-2666 (Online) International Scientific Journal Monte (ISJM) DOI: 10.33807/monte.20211916 Volume 4, (No).2 (2021): April

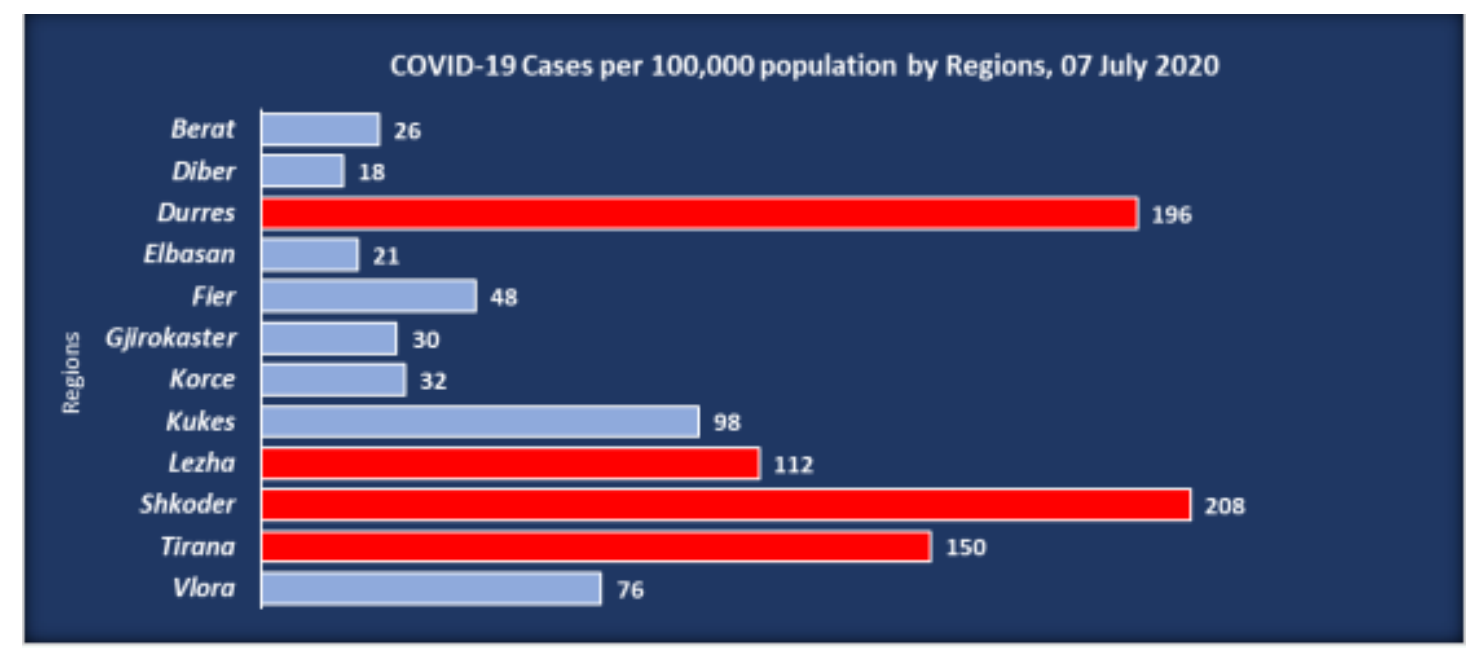

Source: THE COVID-19 CRISIS IN ALBANIA (C OECD 2021

\subsection{ECONOMIC IMPACT/OUTLOOK CORONA VIRUS (COVID-19)}

The pandemic of the new corona virus (COVID-19), in addition to causing a health crisis, has also affected the behavior of people and their daily habits, which has caused changes in the economy, ${ }^{13}$ In this context, certain sectors in the economy are suffering losses, while on the other hand, some sectors are growing.

The crisis caused by COVID-19, in the world, but also in the countries of the region, has mostly affected the tourism sector, as well as other sectors related to tourism, namely hospitality, crafts and transport, but also investments in construction and in numerous other projects, both in the public and private sector. On the other hand, what stands out in the context of changes in the economy is the growth of e-commerce, i.e., online sales during the pandemic.

\subsection{MACROECONOMIC DATA AND GDP IN ALBANIA}

The economy was projected to contract by about $7.5 \%$ in 2020 (vs. $2.2 \%$ in 2019) reflecting its dependence on tourism and remittances. Furthermore, the November 2019 earthquake took an additional toll on economic activity, particularly in 2020. The fiscal deficit was projected to rise to about $7 \%$ of GDP and the public debt to slightly above $80 \%$ of GDP at the end of 2020.

In the second quarter of 2020, Albania ${ }^{14}$ had an economic contraction of $10.2 \%$, followed by a contraction of $3.5 \% \mathrm{y}-\mathrm{o}-\mathrm{y}$ in the third quarter. This recession was first driven by a contraction in investment, private and public consumption, as well as a large fall in exports of $35 \%$. ${ }^{15}$ This drop may be explained by the large share of Albania's exports to Italy (48\%), which in itself fell to a notable recession of almost $18 \%$ in the second quarter of 2020 . However, the recession slowed down due to an improvement in investment growth of $4.1 \%$ as a result of the recent construction projects in the aftermath of the earthquake.

\footnotetext{
${ }^{13}$ Anatolia Agency (AA). 2020

${ }^{14}$ Policy reactions - December 2020/January 2021

${ }^{15}$ This document and any map included herein are without prejudice to the status of or sovereignty over any territory, to the delimitation of international frontiers and boundaries and to the name of any territory, city or area. The use of this work, whether digital or print, is governed by the Terms and Conditions to be found at http://www.oecd.org/termsandconditions.
} 
ISSN 2661-2666 (Online) International Scientific Journal Monte (ISJM) DOI: 10.33807/monte.20211916 Volume 4, (No).2 (2021): April

a) The economic downturn caused by the COVID-19 pandemic, which is mainly observed by a decline in demand, which has no consumers to buy goods and services available in the global economy, is also reflected in Albania.

b) One of the hardest hit sectors is tourism, which this year has a shortage of foreign tourists, compared to previous years.

c) According to the Albanian Association of Tour Operators and Tourist ${ }^{16}$ Agencies, in Albania this summer season there is only 20 percent of the total number of tourists that was forecast in normal time and this has a direct impact on the country's economy.

d) During the measures against the pandemic, many businesses stopped their activity and due to this situation, online sales increased in some sectors. Meanwhile, according to a report of the Bank of Albania, the health emergency caused by the spread of COVID-19 and the measures of public authorities to control it in Albania pose a challenge to the economic and financial stability of the country, to the finances of businesses and families, as well as to the sustainability of the country's economic growth, in the medium and long term.

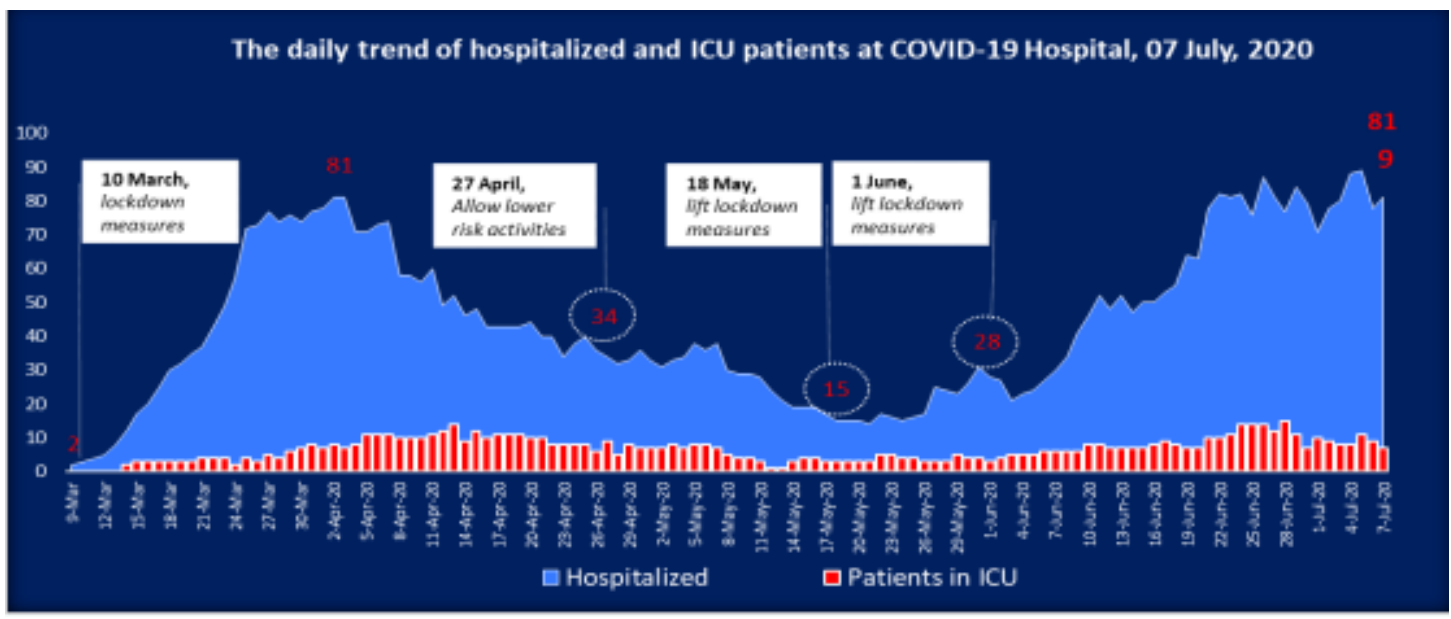

\subsection{ECONOMY DECLINING DURING COVID-19}

Given this situation, according to financial institutions, the double shock of supply and demand will be reflected in the decline of economic activity during 2020, accompanied by declining employment, rising unemployment, declining household incomes and financial difficulties for businesses.

Since March this year, Albania continues to be gripped by the crisis of the pandemic COVID - 19. The number of victims reached on Thursday, 208 people, about 6 times higher than that in the three months of isolation, March- May

Every day, health authorities report more victims and new cases of infection with over 130 per day, which is approaching the number of 7,000 people in total.

The consequences of the crisis in the economy appear severe day by day: business bankruptcy, rising unemployment, declining purchasing power, domestic production and trade exchanges. At the macro

\footnotetext{
${ }^{16}$ Flights from Britain to Albania were suspended from 22 December to 1 February, due to the latest Sars-Cov 2 mutation.

The 2021 state budget for the health sector was increased by $23 \%$, including a $40 \%$ raise for medical staff at the front lines of the COVID-19 pandemic.
} 
leve ${ }^{17}$ there may be an increase in public debt, rising unemployment, contraction of domestic and foreign investment, rising costs of many businesses, etc.

The data show an increase in the number of small and family businesses that have gone bankrupt or temporarily blocked their activity, job losses, and difficulties in fulfilling contracts and financial obligations, difficulties for new contracts in the near future, especially with external partners

a) The short-term risks of global financial stability have been contained as an unprecedented policy response to the corona virus pandemic (COVID-19) has helped avert a financial downturn and maintain credit flow to the economy.

b) For the first time, many emerging market central banks have launched asset acquisition programs to support the smooth functioning of financial markets and the general economy.

c) But the forecast remains very uncertain, and weaknesses are growing, representing the possible smell of recovery.

\section{Figure 4. COVID-19 adaptation measures among firms}

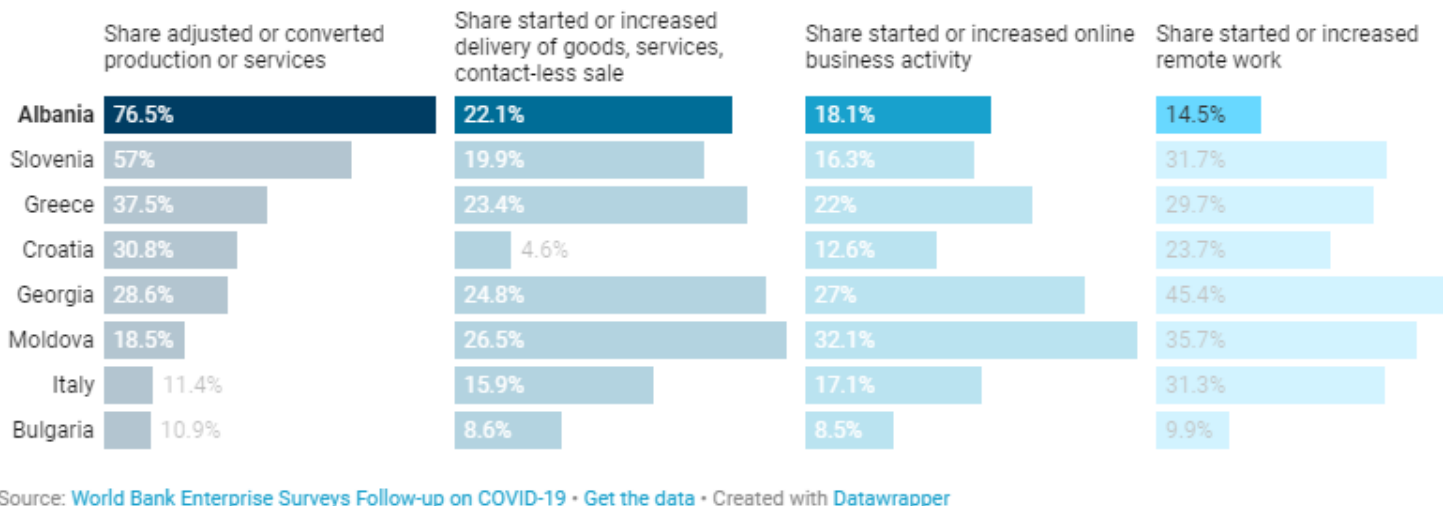

${ }^{18}$ The report presents an assessment of real-financial disconnection, as well as a forward-looking analysis of nonfinancial firms, banks and capital flows into the market. Following the explosion, firms' cash flows were negatively affected as economic activity fell sharply.

a) The most vulnerable firms - those with weaker solvency and liquidity positions and smaller size - experienced greater financial stress than their counterparts in the early stages of the crisis.

b) As the crisis unfolds, corporate liquidity pressures can turn into insolvency, especially if recovery is delayed. Small and medium enterprises (SMEs) are more vulnerable than large firms with access to capital markets. ${ }^{19}$ Although the global banking system is well capitalized, some banking systems may experience capital shortages in an unfavorable scenario, even with the policy measures currently in place.

c) The IMF is responding to an unprecedented number of emergency funding calls - from over 100 countries. The fund has doubled access to its emergency facilities - the Quick Credit Facility (RCF) and the Quick Financing Instrument (RFI) - allowing it to meet the growing demand for financing during the crisis.

\footnotetext{
${ }^{17}$ https://www.unicef.org/albania/media/3101/file/UN\%20ALBANIA\%20COVID-19\%20SOCIOECONOMIC\%20RECOVERY\%20\&\%20RESPONSE\%20PLAN.pdf, pp 12

${ }^{18} \mathrm{https}: / / w w w . u n i c e f . o r g / a l b a n i a / m e d i a / 3101 / f i l e / U N \% 20 A L B A N I A \% 20 C O V I D-19 \% 20$ SOCIOECONOMIC\%20RECOVERY\%20\&\%20RESPONSE\%20PLAN.pdf, pp 21

${ }^{19}$ See: Georgia has similar income per capita and strong tourism as Albania; Moldova is a lower income country with large outmigration and remittances inflows; Italy and Greece are Albania's main trade partners with strong tourism sectors; Bulgaria and Slovenia are somewhat similar small economies in a

more advanced stage of transition; and Croatia is a Western Balkan country with a strong tourism sector. Other countries in ECA where the same survey was undertaken include Cyprus, Czech Republic, North Macedonia, Poland, Romania and the Russian Federation, pp 4
} 
d) ${ }^{20}$ These facilities allow the Fund to provide emergency assistance without having to have a complete program. Emergency funding has already been approved by the IMF Executive Board at a record speed for 76 countries. As of June 2020, the IMF has also provided financing under other lending arrangements. Please see the IMF Financial Aid and Debt Service Assistant COVID-19 tracker where you can find the latest detailed information.

Any member of the IMF can apply for emergency assistance. There are several requests for support under the Quick Credit Instrument (RCF) and the Quick ${ }^{21}$ Credit Instrument (RFI), including whether the county debt is stable or on track to be stable, which has urgent balance needs and is pursuing broadly appropriate policies to address the crisis (including safeguards to ensure that IMF funds are used for their intended purposes).

The policy steps we know have worked before - including during the GFC - are on the table. Yesterday, major central banks took decisive coordinated action to facilitate exchange lines and thus reduce global financial market stresses.

Financial system supervisors should aim to maintain a balance between maintaining financial stability, maintaining the health of the banking system, and maintaining economic activity.

This crisis will prove stressful if the changes made after the financial crisis will serve their purpose.

a) Banks should be encouraged to use flexibility in existing regulations, for example by using their capital and liquidity safeguards, and undertake renegotiation of loan terms for stressed borrowers.

b) Risk detection and clear communication of supervisory expectations will also be essential for markets to function properly in the period ahead.

Albania was slightly affected in the first wave of the pandemic in the spring. Due to its proximity and close ties to Italy, Albania adopted some of the most difficult blocking measures in Europe on Mars as soon as it discovered the first confirmed COVID-19 case. The government declared a state of natural disaster which enabled it to use the extended powers for its three-month duration until it expired on 23 June.

a) The Bank of Albania suspended the distribution of dividends to banks until the end of 2020 in order to increase capital and support loans during this period. The central bank also halved the salaries of its supervisory board and senior management for as long as the pandemic lasted.

b) To promote and reduce the use of online banking the number of people seeking services on the bank premises, the central bank also waived commissions for transfers in local currency.

\section{CONCLUSIONS}

COVID-19 disrupted the normal environment in which children used to live and grow and drastically affected their access to critical services. ${ }^{22}$ Country wide lockdown left those who had homes, residential care placement or shelter in quarantine and those whose livelihood was already linked to working and living in the street, in even worse and uncertain situation. COVID-19 pandemic has increased the risk for child labor and child exploitation, as many families see their income and livelihood sources diminish.

\footnotetext{
${ }^{20}$ Quick Credit Facility (RCF) and the Quick Financing Instrument (RFI)

${ }^{21}$ See: The International Institute of Finance (IIF) responded to this initiative by recommending that private sector creditors repay debt in a similar way. In May, the IIF issued Terms of Reference for private sector participation on a voluntary basis.

The IMF, together with the World Bank, has expressed support for a further extension of the DSSI by the end of 2021. The G20 have agreed to consider the need for a further extension until the time of the IMF-World Bank Spring Meetings in April 2021

https://www.unicef.org/albania/media/3101/file/UN\%20ALBANIA\%20COVID-19\%20SOCIO-

ECONOMIC\%20RECOVERY\%20\&\%20RESPONSE\%20PLAN.pdf
} 
${ }^{23}$ For children already living, working or spending most of their time in a street-connected situation, this risk is extremely high, and demands for immediate support to provide support services to these children and their families, while helping them keep the pace of their education, access to vocational training and other developmental opportunities.

COVID-19 has exposed the seriousness of the mass emigration of health workers from the Western Balkans and how important it is to keep medical personnel in the country. ${ }^{24}$ The pandemic also revealed the systemic weaknesses of the health system, a consequence of few decades of investment in people, facilities and equipment. In the end, it fully exposed the lack of investment over the decades from the Western Balkan countries in education, science and research and development. On average, these countries spend less than 0.4 percent of GDP on research and development. Fewer vehicle movements brought migratory movement of birds and mammals faster than usual and reduced air pollution.

The survey underscores the severity of the pandemic's impact on Albanian firms. The government's most important firm-level support appears to have been wage subsidies which is an effective instrument for temporary shocks. If the COVID-19 crisis prolongs, providing further wage subsidies will be challenging given the limited fiscal space. The government will likely have to continue making difficult choices, and the private sector will likely need to make further adjustments.

\footnotetext{
${ }^{23}$ The International Institute of Finance (IIF) responded to this initiative by recommending that private sector creditors repay debt in a similar way. In May, the IIF issued Terms of Reference for private sector participation on a voluntary basis.

The IMF, together with the World Bank, have expressed support for a further extension of the DSSI by the end of 2021. The G20 have agreed to consider the need for a further extension until the time of the IMF-World Bank Spring Meetings in April 2021, pp 11,17

${ }^{24}$ The International Institute of Finance (IIF) responded to this initiative by recommending that private sector creditors repay debt in a similar way. In May, the IIF issued Terms of Reference for private sector participation on a voluntary basis. The IMF, together with the World Bank, have expressed support for a further extension of the DSSI by the end of 2021. The G20 have agreed to consider the need for a further extension until the time of the IMF-World Bank Spring Meetings in April 2021, pp 32
} 